\title{
Analisis Kualitas Berkas Radiasi LINAC Untuk Effektivitas Radioterapi
}

\author{
Rahma Ajeng Puspitasari ${ }^{1}$, Wahyu Intan Pertiwi ${ }^{1}$, Putri Maratus Sholihah ${ }^{2}$, Wafilda \\ Himmatul Fariqoh ${ }^{2}$, Nandia Kavilani ${ }^{2}$, Suryani Dyah Astuti*2 \\ ${ }^{1}$ Magister Teknik Biomedis, Fakultas Sains dan Teknologi, Universitas Airlangga, Surabaya \\ ${ }^{2}$ Departemen Fisika, Fakultas Sains dan Teknologi, Universitas Airlangga, Surabaya \\ ${ }^{3}$ Instalasi Radioterapi Rumah Sakit Angkatan Laut Dr. Ramelan, Surabaya \\ e-mail: *suryanidyah@ fst.unair.ac.id
}

\begin{abstract}
Abstrak
Kanker merupakan salah satu menyebabkan kematian tinggi di dunia. Salah satu metode untuk terapi kanker adalah radioterapi menggunakan sinar-X. Sinar-X dipercepat dan diarahkan menggunakan perangkat Linac. Penelitian tentang analisis kualitas berkas radiasi Linac dilakukan di Departemen Radiologi Rumah Sakit Dr. Ramelan Surabaya. Metode dilakukan dengan observasi dan membandingkannya dengan batas toleransi TRS 389 IAEA. Digunakan fantom sebagai peraga obervasi. Dari hasil pengukuran dan perhitungan terhadap keluaran berkas radiasi pesawat LINAC didapatkan: pada berkas foton dengan variasi energi $6 \mathrm{MV}$ didapatkan nilai keluaran per $1 \mathrm{MU}$ adalah 0,9938 cGy dengan penyimpangan pengukuran 1,173\% . Pada berkas elektron dengan variasi energi $6 \mathrm{MeV}$ dan $10 \mathrm{MeV}$ didapatkan nilai keluaran per $1 \mathrm{MU}$ masing-masing adalah 0,9925 cGy dan 1,0133 cGy dengan penyimpangan pengukuran 0,752 \% dan 1,331\%. Kualitas keluaran berkas radiasi (berkas foton dan elektron) pesawat terapi LINAC di RSAL Dr Ramelan Surabaya telah sesuai dengan standar TRS 398 IAEA, penyimpangan masing-masing berkas masih dalam batas toleransi yaitu $\pm 2 \%$ untuk fantom padat, untuk itu dosis output dari pesawat LINAC di RSAL Dr Ramelan Surabaya sesuai dengan batas dosis yang dibutuhkan oleh setiap pasien berdasarkan asas proteksi radiasi, sehingga masih aman digunakan untuk pengobatan radioterapi.
\end{abstract}

Kata kunci—radiasi, radioterapi, Linac, phantom .

Abstract

Cancer is one of the leading causes of high mortality in the world. One method for cancer therapy is radiotherapy using X-rays. X-rays are accelerated and directed using a Linac device. Research on the analysis of the quality of the Linac radiation beam was carried out in the Radiology Department of Dr. Hospital. Ramelan Surabaya. The method is carried out by observation and comparing it with the tolerance limit of TRS 389 IAEA. Phantom used to be observed object. From the results of measurements and calculations of the LINAC aircraft beam radiation output obtained: the photon beam with an energy variation of $6 \mathrm{MV}$ obtained the output value per 1 MU is 0.9938 cGy with a measurement deviation of $1.173 \%$. In the electron beam with energy variations of $6 \mathrm{MeV}$ and $10 \mathrm{MeV}$, the output values per 1 $M U$ are $0.9925 c G y$ and $1.0133 c G y$ with measurement deviations of $0.752 \%$ and $1.331 \%$, respectively. The quality of the radiation beam output (photon and electron beam) of LINAC therapy aircraft at RSAL Dr. Ramelan Surabaya is in accordance with the TRS 398 IAEA standard, the deviation of each beam is still within the tolerance range of $\pm 2 \%$ for solid phantom, for that the output dose of the LINAC aircraft at Dr Ramelan Hospital in Surabaya according to the dose limit required by each patient based on the principle of radiation protection, so it is still safe to use for radiotherapy treatment.

Keywords—radiation, radiotherapy, Linac, phantom 


\section{PENDAHULUAN}

Kanker merupakan salah satu penyakit yang menyebabkan kematian yang tinggi di dunia. Berdasarkan data WHO terdapat 9,6 juta kematian yang diakibatkan oleh kanker pada tahun 2018 (WHO, 2018). Karena tingkat yang tinggi para peneliti dituntut untuk terus meningkatkan kebaharuan di bidang pengobatan kanker. Berbagai metode telah dikembangkan untuk mengobati kanker dan salah satunya dengan terapi radiasi atau radioterapi. Berdasarkan International Agency for Research on Cancer (IARC) dari sekitar seluruh penderita kanker terdapat $50 \%$ yang membutuhkan radioterapi.

Radioterapi merupakan metode pengobatan menggunakan radiasi pengion (sinar-X). Proses ionisasi ini merupakan hasil interaksi antara radiasi pengion dengan sel kanker yang membuat untai DNA kanker terputus dan menyebabkan kematian sel (Immel et al, 2016). Untuk itu perlu diusahakan supaya dosis radiasi yang diberikan pada sel kanker harus terdistribusi secara merata dan sebisamungkin meminimalisasi dosis radiasi yang jatuh di luar area penyinaran. Rentang energi elektron untuk keperluan radioterapi adalah sebesar (6-29) MeV (Podgorsak, 2003).

Linear Accelerator (Linac) merupakan instrumen yang digunakan untuk mempercepat pergerakan elektron. Partikel bermuatan dipercepat dengan diberi medan listrik dan medan magnet sehingga mencapai kecepatan yang sangat tinggi. Partikel yang dipercepat dapat digunakan untuk memenghasilkan sinar-X berenergi tinggi (Astuti and Kholimatussa'diah, 2019). Berkas foton biasanya terdiri dari variasi energi $8 \mathrm{MV}$ dan 10 $\mathrm{MV}$, sedangkan berkas elektron biasanya terdiri dari variasi energi $(4,6,9,12,15$, dan 18) $\mathrm{MeV}$. Berkas foton digunakan untuk menyinari kanker yang berada pada jaringan dalam misalnya kanker payudara, kanker serviks, dan kanker nasofaring, sedangkan berkas elektron digunakan untuk menyinari kasus kanker kulit.

Pengukuran dosis pada radioterapi harus dilakukan dengan tepat dan sesuai standar. Perhitungan dosis juga harus mengikuti protokol Technical Report Series (TRS) 398 yang dikeluarkan oleh International Atomic Energy
Agency (IAEA) pada akhir tahun 2000. TRS 398 adalah suatu kode praktis Internasional untuk dosimetri berdasarkan standar dosis serap air yang dijadikan sebagai pedoman dalam penentuan dosis serap berkas radiasi pesawat terapi eksternal. TRS 398 merekomendasikan penggunaan detektor ionisasi chamber plane parallel untuk elektron dan detektor ionisasi chamber farmer untuk foton energi tinggi dengan pengukuran berkas radiasi dikalibrasi langsung di dalam air atau fantom air. Pengukuran kualitas keluaran berkas radiasi (berkas foton dan elektron) pesawat terapi Linac perlu dilakukan pada setiap pesawat terapi secara berkala, karena dalam setiap peyinaran besar energi yang keluar harus sama dengan yang dibutuhkan oleh setiap pasien dan sesuai asas proteksi radiasi, serta untuk mengetahui kualitas keluaran berkas radiasi pada pesawat masih dalam jangkauan normal atau tidak, untuk itu kami melakukan penelitian mengenai analisis kualitas keluaran berkas radiasi pesawat terapi Linac di Rumah Sakit Dr Ramelan Surabaya.

\section{LINAC: DEFINISI DAN CARA KERJA}

Linac merupakan alat yang dirancang untuk mempercepat pergerakan elektron secara linier sehingga dapat menghasilkan berkas foton dan berkas elektron (Astuti and Kholimatussa'diah, 2019). Linac menggunakan gelombang elektromagnetik dengan frekuensi tinggi untuk mempercepat partikel bermuatan seperti elektron dengan energi tinggi saat melewati tabung linear. Elektron berenergi tinggi tersebut bisa digunakan untuk mengobati kanker pada kedalaman yang dangkal, atau elektron tersebut dikenakan pada target sehingga menghasilkan foton untuk mengobati kanker dengan kedalaman yang cukup jauh. Linac memiliki dosis yang seragam dengan foton energi tinggi dan berkas elektron pada bagian kanker pasien. Proses ionisasi sebagai hasil dari interaksi radiasi pengion (berkas foton dan elektron) dengan materi (kanker) akan membuat rantai deoxyribose nucleic acid (DNA) kanker terputus sehingga dapat mematikan jaringan kanker tersebut. Input yang dibutuhkan adalah jumlah dalam monitor unit (MU). Jumlah MU ini 
bergantung pada besar dosis yang akan disampaikan, kedalaman kanker, laju dosis referensi/kalibrasi monitor, ukuran pengaturan kolimator, luas lapangan kanker dan variabelvariabel lainnya (Khan, 2005).

Elektron merupakan sumber awal radiasi yang dikenakan ke pasien. Elektron pada pesawat terapi Linac bersumber dari elektron gun. Kemudian elektron tersebut dipercepat oleh gelombang mikro yang disuplai dari magnetron menjadi elektron berenergi tinggi. Proses mempercepat elektron dilakukan di dalam sebuah tabung yang disebut acceleratingr wave guide (accelerator tube). Selanjutnya elektron yang telah dipercepat oleh gelombang mikro akan dilewatkan ke magnet pembelok. Magnet pembelok akan membelokkan berkas elektron sebesar $90^{\circ}$, agar berkas elektron dapat diarahkan sesuai dengan keperluan radiasi. Pada magnet pembelok elektron dengan energi yang sedikit lebih tinggi atau lebih rendah dari yang dikehendaki, akan dibelokkan sedemikian rupa sehingga energi dan lintasannya dapat sesuai kembali dengan yang dikehendaki (Linskey et al 2015). Gambar Linac secara medik dapat dilihat pada Gambar 1.

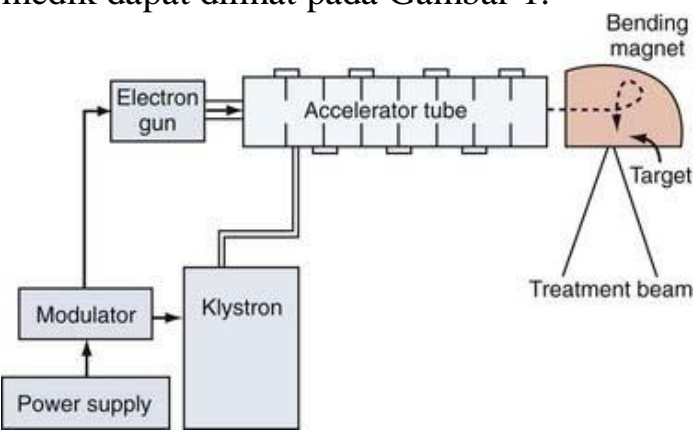

Gambar 1. Linac medis (Linskey et al 2015)

Fantom merupakan suatu bentuk permodelan dari objek manusia yang digunakan dalam bidang radiologi baik radiodiagnostik maupun radioterapi untuk evaluasi kualitas gambar radiograf secara realistis (Vinny, 2018). Fantom mempunyai sifat menyerap dan menghamburkan berkas mendekati jaringan. Material fantom yang digunakan harus memiliki sifat mendekati suatu material (misalnya jaringan atau udara), paling tidak dalam tiga parameter yaitu densitas massa, jumlah elektron per gram dan nomor atom efektif. Fantom yang banyak digunakan yaitu fantom yang terbuat dari akrilik karena mempunyai rapat massa yang hampir sama dengan kerapatan air yakni 0,994 gr/cm3, hal ini dilakukan karena manusia terdiri dari $75 \%$ molekul air. Untuk keperluan pengukuran foton maupun elektron, air dipakai sebagai fantom standar ekuivalen jaringan, karena air mempunyai kemampuan menyerap foton hampir sama dengan jaringan basah. Sedangkan untuk menjaga keamanan alat ukur yang digunakan seperti dosimeter TLD, maka selain fantom cair juga dibuat fantom padat yang dimodifikasi sehingga kedap air. Fantom padat yang digunakan memiliki densitas yang mendekati jaringan tubuh manusia.

Keluaran berkas radiasi Linac pada solid phantom ditentukan dengan pengukuran menggunakan fantom padat, luas lapangan penyinaran $(10 \times 10) \mathrm{cm}$, dan source to surface distance (SSD) $100 \mathrm{~cm}$. Perhitungan kualitas keluaran berkas radiasi diperlukan adanya nilai jumlah cacahan referensi. Nilai jumlah cacahan referensi diperoleh dari pengukuran pertama menggunakan solid phantom setelah dilakukan pengukuran dengan water phantom. Nilai keluaran yang dihasilkan terhadap referensi akan menghasilkan nilai cGy/MU yang merupakan keluaran berkas radiasi yang dicari. Nilai keluaran terhadap referensi dihitung dengan menggunakan Persamaan 2.1.

Nilai keluaran terhadap referensi $=$ keluaran berkas (cGY)

Berkas referensi $(M U)$....

Penyimpangan (deviasi) dari dosis output (Keluaran) dari pesawat terapi Linac terhadap nilai acuan sesuai TRS No. 398 IAEA yaitu 1 cGy/MU dihitung dengan menggunakan Persamaan 2.2.

Deviasi

$=$

$\underline{\text { Jumlah cacahan didapat-Jumlah cacahan referen }} \times$ $100 \%$

\section{METODE PENELITIAN}

\section{Waktu dan Tempat Penelitian}

Kegiatan penelitian ini dilakukan di Sub Departemen Radioterapi Rumah Sakit Angkatan Laut (RSAL) Dr. Ramelan 
Jurnal Biosains Pascasarjana Vol. 22 (2020) pp

(C) (2020) Sekolah Pascasarjana Universitas Airlangga, Indonesia

Surabaya. Penelitian dilakukan mulai 6 Januari hingga 24 Januari 2020.

\section{Alat dan Bahan}

Bahan yang digunakan pada studi observasi pada penelitian ini adalah akrilik sebagai bahan fantom padat. ini adalah

Alat yang digunakan dalam penelitian a. Pesawat Terapi Linear Accelerator (Linac), dengan spesifikasi merek Elekta tipe precise treatment, dengan energi foton 6 dan $10 \mathrm{MV}$, dan energi elektron 4,6,9,12,15 dan $18 \mathrm{MeV}$.

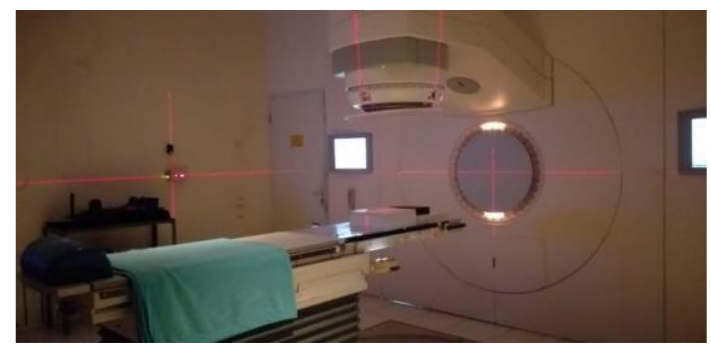

Gambar 1 Linear Accelerator (Linac)

b. Detektor (Ion Chamber)

Untuk membedakan energi agar tegangan kerja yang dibutuhkan tidak terlalu tinggi. Sedangkan field detector yang digunakan adalah Waterproof $0,6 \mathrm{cc}$.

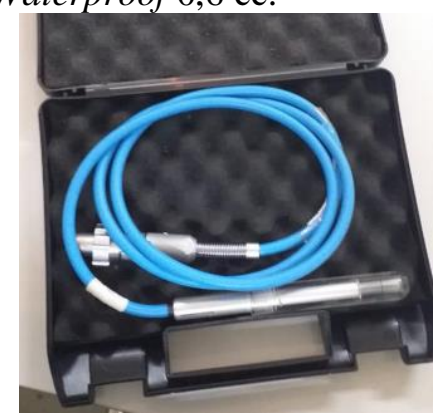

Gambar 2 Ion Chamber

c. Perangkat komputer 
Jurnal Biosains Pascasarjana Vol. 22 (2020) pp

(C) (2020) Sekolah Pascasarjana Universitas Airlangga, Indonesia

Komputer digunakan untuk mengontrol dalam pengukuran kualitas keluaran berkas radiasi, mulai dari memasukkan parameter yang dibutuhkan dalam pengukuran (suhu, tekanan udara, dll), hingga akhirnya nilai cacahan hasil pengukuran dapat dilihat pada komputer. Komputer dihubungkan dengan perangkat PTW yang berfungsi mengubah energi radiasi menjadi tercacah (dapat terhitung).

\section{d. Kabel Penghubung}

Di dalamnya berisi emas untuk menyambungkan berbagai komponen dan alat yang digunakan dalam pengukuran.

\section{e. Termometer dan Barometer}

Dalam pengukuran digunakan termometer barometer ruangan digital untuk mengukur temperatur dan tekanan udara bersamaan. Temperatur dan tekanan udara yang tercatat digunakan sebagai salah satu parameter dalam pengukuran.

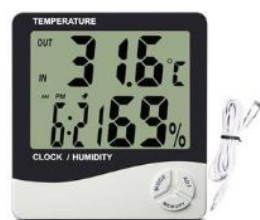

Gambar 5 Alat Pengukur Termometer dan Barometer.

\section{f. Fantom}

1.) Fantom air

Fantom Air digunakan sebagai pengganti pasien untuk mengukur keluaran berkas foton dan elektron. Pengukuran fantom air dilakukan sebulan sekali sebelum pengukuran fantom padat dilakukan.

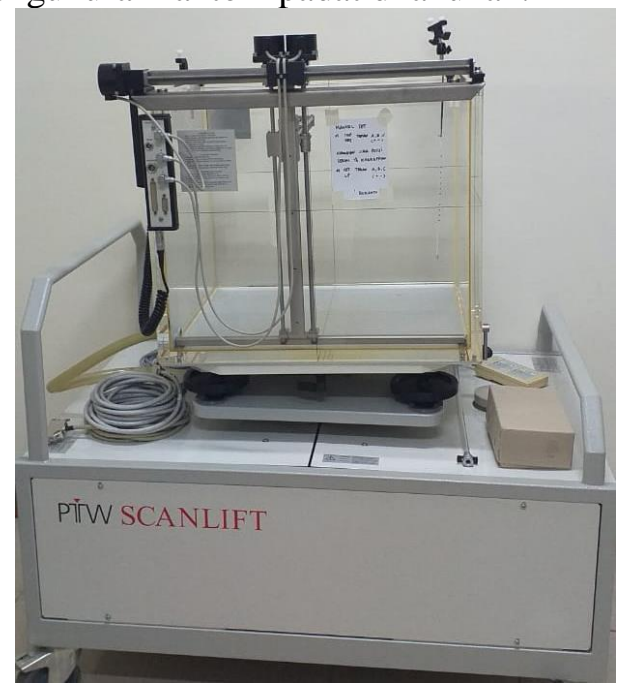

Gambar 6 Fantom air (water phantom)
2.) Fantom padat

Phantom padat digunakan untuk mengukur keluaran berkas foton dan elektron. Digunakan pada pengukuran kualitas keluaran berkas radiasi mingguan setalah dilakukan pengukuran dengan water phantom.

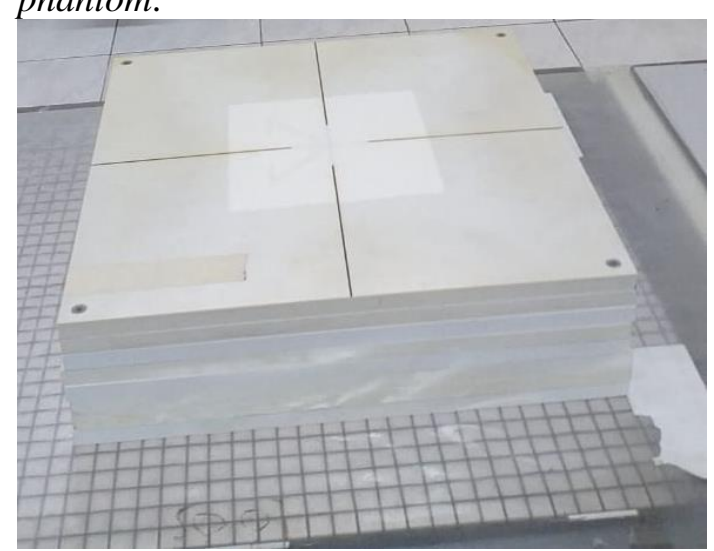

Gambar 7 Fantom Padat (Solid Phantom) 


\section{Pengukuran Berkas Foton}

Kegiatan dilakukan dengan observasi langsung melalui penggunaan CT Simulator dan Setting pesawat Linac yang ada pada sub departemen radiologi RSAL Dr. Ramelan. Kemudian dilakukan pengukuran radiasi yang terpancar pada daerah sekitar ruang Linac (proteksi radiasi). Observasi dilakukan langsung mengguanakan CT Simulator dan setting pesawat Linac. Keluaran berkas radiasi diukur dengan pesawat terapi Linac menggunakan media fantom padat (solid phantom). Observasi dilakukan langsung menggunakan CT Simulator dan Setting pesawat Linac. Kemudian dilakukan analisis.

\section{Proses Pengukuran Keluaran Berkas Radiasi}

Posisi kedalaman dalam pengukuran tidak terdapat patokan, namun nilai kedalaman harus tetap sama dari proses pengukuran awal hingga akhir. Sedangkan dalam pengukuran keluaran berkas elektron luas lapangan yang digunakan adalah $10 \times 10$ (Bencheikh et al, 2017).

Tabel 1. Proses pengukuran keluaran berkas foton

\begin{tabular}{lccc}
\hline Parameter Uji & Toleransi & $\begin{array}{c}\text { Nilai Level } \\
\text { Tindakan }\end{array}$ & Langkah Kerja \\
\hline Konstansi & $1-2 \%$ & $>2 \%$ dan berulang & Mengatur gantri dan kolimator tegak \\
keluaran foton & & pada rentang & lurus terhadap detektor. \\
(pengukuran & & $\begin{array}{c}\text { pengukuran 1 } \\
\text { minggu }\end{array}$ & $\begin{array}{c}\text { Memposisikan fantom dan detektor } \\
\text { absolut) }\end{array}$ \\
& & $\begin{array}{c}\text { Melakuai protokol IAEA TRS-398. } \\
\text { protokol IAEA TRS-398 }\end{array}$ \\
\hline
\end{tabular}

Tabel 2. Proses pengukuran keluaran berkas elektron

\begin{tabular}{lccc}
\hline Parameter Uji & Toleransi & $\begin{array}{c}\text { Nilai Level } \\
\text { Tindakan }\end{array}$ & Langkah Kerja \\
\hline Konstansi & $1-2 \%$ & $>2 \%$ dan & Mengatur gantri dan kolimator tegak lurus \\
keluaran & & berulang & terhadap detektor \\
elektron & pada rentang & Memasang aplikator referensi \\
(pengukuran & & $\begin{array}{c}\text { pengukuran } \\
\text { absolut) }\end{array}$ & Memposisikan phantom dan detektor sesuai \\
& & protokol IAEA TRS-398 \\
& & $\begin{array}{c}\text { Melakukan pengukuran sesuai dengan } \\
\text { protokol IAEA TRS-398 }\end{array}$ \\
\hline
\end{tabular}

\section{HASIL DAN PEMBAHASAN}

Pengukuran kualitas keluaran pesawat Linac merupakan bagian dari program QA dan QC dari fasilitas radioterapi. QA merupakan program teratur yang bertujuan menjamin konsistensi tahapan medik. Sedangkan QC adalah tindakan pengukuran yang rutin dilakukan untuk memonitor performa visual dan uji kinerja dari peralatan sehingga kualitas dari keluaran dapat dijamin. Salah satu rangkaian dari QA dan QC adalah kalibrasi atau pengukuran dosis yang meliputi kalibrasi harian, kalibrasi mingguan, dan kalibrasi bulanan. Dalam Instalasi Radioterapi RSAL Dr. Ramelan Surabaya dilakukan kalibrasi bulanan dengan menggunakan phantom air (water phantom) dan kalibrasi mingguan dengan menggunakan phantom padat (solid phantom). Dalam studi kali ini, kualitas keluaran dosis radiasi yang dikaji adalah kalibrasi mingguan dengan menggunakan solid phantom yang diukur 1 minggu sekali.

\subsection{Hasil Penghitungan Kualitas Keluaran Berkas Radiasi}

Perencanaan terapi dan pemberian dosis yang tepat akan menentukan keberhasilan radioterapi. Dengan demikian diperlukan suatu jaminan mutu dan kendali mutu berkas radiasi secara berkala untuk mencapai keberhasilan pengobatan secara maksimal. Untuk itu diperlukan adanya pengukuran keluaran berkas radiasi pada 
Jurnal Biosains Pascasarjana Vol. 22 (2020) pp

(C) (2020) Sekolah Pascasarjana Universitas Airlangga, Indonesia

perangkat radioterapi, dalam hal ini yang dikaji yaitu pesawat Linac.

Pengukuran keluaran berkas radiasi (berkas foton dan elektron) pada pesawat terapi Linac dilakukan untuk mengetahui kondisi pesawat terapi Linac selama digunakan tetap mengacu pada nilai $1 \mathrm{cGy}$ sama dengan $1 \mathrm{MU}$ (monitor unit), agar berkas radiasi yang keluar dari pesawat terapi sesuai dengan kebutuhan pasien dan dosis radiasi yang diterima pasien sesuai dengan kebutuhan serta sesuai asas proteksi radiasi. Berkas radiasi yang keluar dari linac dan diterima oleh media (phantom) harus sama (konsisten) yaitu tidak boleh lebih dari $2 \%$ untuk solid phantom dan tidak lebih dari
3\% untuk water phantom (Tsiamas et al, 2014).

Dalam pengukuran kualitas keluaran berkas radiasi yang dilakukan selama praktek kerja lapangan hanya dilakukan pengukuran keluaran berkas radiasi dengan solid phantom. Hal itu dikarenakan pengukuran dengan water phantom yang hanya dilakukan sebulan sekali dan membutuhkan waktu yang cukup lama sehingga akan menghambat proses pelayanan pasien yang akan di terapi dengan menggunakan Linac (Pratiwi, 2006).

Pengukuran dilakukan dengan berkas radiasi foton 6MV dan berkas elektron $6 \mathrm{MeV}$ dan $10 \mathrm{Mev}$. Pengukuran dilakukan sebanyak 3 kali untuk tiap energi agar mendapatkan hasil yang lebih teliti.

Tabel 3 Hasil Pengukuran Kualitas Keluaran

\begin{tabular}{|c|c|c|c|c|c|c|c|}
\hline \multirow{2}{*}{$\begin{array}{l}\text { Temperatur } \\
19^{\circ}\end{array}$} & \multirow{2}{*}{$\begin{array}{l}\text { Kelembaban } \\
55 \%\end{array}$} & \multirow{2}{*}{$\begin{array}{l}\text { Tekanan } \\
1009\end{array}$} & \multirow{2}{*}{$\begin{array}{c}\text { Energi } \\
6 \mathrm{MV}\end{array}$} & \multicolumn{3}{|c|}{$\begin{array}{c}\text { Jumlah Cacahan Berkas } \\
\text { Radiasi }\end{array}$} & \multirow{2}{*}{$\begin{array}{c}\begin{array}{c}\text { Rata- } \\
\text { rata }\end{array} \\
35,38\end{array}$} \\
\hline & & & & 35,37 & 35,39 & 35,37 & \\
\hline & & & $6 \mathrm{MeV}$ & 35,61 & 35,58 & 35,61 & 35,60 \\
\hline & & & $10 \mathrm{MeV}$ & 36,51 & 36,53 & 36,54 & 36,53 \\
\hline
\end{tabular}

Untuk memperoleh hasil pengukuran, dibutuhkan nilai referensi cacahan berkas radiasi. Nilai referensi cacahan berkas radiasi didapatkan dari pengukuran solid phantom pertama yang dilakukan setelah pengukuran water phantom tiap bulannya. Nilai referensi cacahan berkas radiasi dinyatakan dalam Tabel 4.

Tabel 4. Nilai keluaran radiasi referensi

\begin{tabular}{lc}
\hline Energi & $\begin{array}{c}\text { Jumlah Cacahan } \\
\text { Berkas Radiasi } \\
\text { Referensi }\end{array}$ \\
\hline $6 \mathrm{MV}$ & 35,80 \\
$6 \mathrm{MeV}$ & 35,87 \\
$10 \mathrm{MeV}$ & 36,05 \\
\hline
\end{tabular}

Berdasarkan hasil pengukuran yang didapat dan jumlah cacahan referensi nilai keluaran terhadap referensi didapatkan dengan menggunakan Persamaan 2.1

Selanjutnya untuk mendapatkan nilai deviasi, hasil nilai keluaran terhadap referensi dibandingkan dengan nilai acuan (referensi dosis keluaran) yaitu $1 \mathrm{cGy} / \mathrm{MU}$. Nilai deviasi juga dapat diperoleh dari Persamaan 2.2.

Sehingga, jika data yang telah diperoleh hasil sebagai berikut :
Tabel 5. Hasil perhitungan

\begin{tabular}{lccc}
\hline $\begin{array}{c}\text { Jenis } \\
\text { Berkas } \\
\text { Radiasi }\end{array}$ & Energi & $\begin{array}{c}\text { Nilai } \\
\text { keluaran } \\
\text { terhadap } \\
\text { referensi } \\
\text { (cGy/MU) }\end{array}$ & $\begin{array}{c}\text { Deviasi } \\
\text { keluaran } \\
\text { berkas } \\
\text { radiasi } \\
(\%)\end{array}$ \\
\hline Foton & $6 \mathrm{MV}$ & 0,9882 & 1,173 \\
\hline Elektron & $6 \mathrm{MeV}$ & 0,9925 & 0,752 \\
& $10 \mathrm{MeV}$ & 1,0133 & 1,331 \\
\hline
\end{tabular}

Berdasarkan Tabel 5, keluaran berkas foton yang diperoleh pada energi $6 \mathrm{MV}$ masih mengacu pada nilai $1 \mathrm{cGy} / \mathrm{MU}$. Berdasarkan TRS 398 IAEA nilai keluaran berkas foton seharusnya $1 \mathrm{cGy} / \mathrm{MU}$, maka nilai keluaran berkas foton pada energi 6 MV memiliki penyimpangan sebesar $0,61 \%$. Hasil keluaran berkas foton yang diperoleh masih berada dalam batas toleransi TRS No. 398 IAEA yaitu $\pm 2 \%$ (Pratiwi, 2010).

Berdasarkan Tabel 5 keluaran berkas elektron yang diperoleh pada energi $6 \mathrm{MeV}$ dan $10 \mathrm{MeV}$ masih mengacu pada nilai 1 cGy/MU. Berdasarkan TRS 398 IAEA nilai keluaran berkas elektron seharusnya 1 cGy/MU, maka nilai keluaran berkas elektron pada energi $6 \mathrm{MeV}$ memiliki 
penyimpangan sebesar $0,76 \%$. Dan nilai keluaran berkas elektron pada energi 10 $\mathrm{MeV}$ memiliki penyimpangan sebesar $1,33 \%$. Hasil keluaran berkas elektron dari 2 energi yang diperoleh masih berada dalam batas toleransi TRS No. 398 IAEA yaitu \pm $2 \%$.

Nilai deviasi yang masih berada dalam batas toleransi TRS No. 398 IAEA yaitu \pm $2 \%$ untuk solid phantom menunjukkan bahwa pesawat terapi Linac masih aman untuk digunakan dalam terapi pasien. Pengukuran ini penting dilakukan untuk mengetahui apakah pesawat terapi yang digunakan pada pasien aman dan dapat memberikan hasil maksimal pada pasien. Nilai deviasi yang berada pada batas toleransi dapat menunjukkan bahwa dosis yang dikeluarkan oleh Linac dan dosis yang diterima oleh tubuh pasien sama atau tidak berbeda jauh, sehingga perencanaan radioterapi dapat maksimal dan meminimalisir jaringan normal disekitar jaringan tumor terpapar radiasi. Selain itu perencanaan radioterapi yang dijalankan oleh petugas medis terhadap pasien juga dapat maksimal. Jika terdapat penyimpangan yang signifikan pada keluaran berkas radiasi Linac, maka wajib dilakukan adjustment untuk penyesuaian pada panel control software Linac agar diperoleh nilai deviasi yang lebih rendah dan dapat memenuhi batas toleransi TRS No. 398 IAEA.

\section{KESIMPULAN DAN SARAN}

Dari hasil pengukuran dan perhitungan terhadap keluaran berkas radiasi (berkas foton dan elektron) pesawat terapi Linac didapatkan: Pada berkas foton dengan variasi energi 6 MV didapatkan nilai keluaran per 1 MU adalah 0,9938 cGy dengan penyimpangan pengukuran $1,173 \%$. Pada berkas elektron dengan variasi energi 6 $\mathrm{MeV}$ dan $10 \mathrm{MeV}$ didapatkan nilai keluaran per 1 MU masing-masing adalah 0,9925 cGy dan 1,0133 cGy dengan penyimpangan pengu-kuran $0,752 \%$ dan $1,331 \%$.

2. Kualitas keluaran berkas radiasi (berkas foton dan elektron) pesawat terapi Linac di RSAL Dr Ramelan Surabaya telah sesuai dengan standar TRS 398 IAEA, penyim- pangan masing-masing berkas masih dalam batas toleransi yaitu $\pm 2 \%$ untuk fantom padat, untuk itu dosis output dari pesawat LINAC di RSAL Dr Ramelan Surabaya sesuai dengan batas dosis yang dibutuhkan oleh setiap pasien berdasarkan asas proteksi radiasi,sehingga masih aman digunakan untuk pengobatan radioterapi.

\section{UCAPAN TERIMA KASIH}

Ucapan Terima Kasih kami sampaikan kepada Departemen Radiologi Rumah Sakit Angkatan Laut DR. Ramelan Surabaya, yang telah memberikan kami kesempatan untuk melakukan penelitian ini.

\section{DAFTAR PUSTAKA}

Astuti, S.D. and Kholimatussa'diah, S. 2019. Dasar Fisika Radiasi dan Dosimetri. Airlangga University Press. Surabaya

Bencheikh M, Maghnouj A, Tajmouat J and Didi A, 2017. Study of Photon Beam Dosimetry Quality for Removing Flattering Filter Linac Configuration, Physics AUC (27): 50-60

IAEA. 2000. Technical Report Series No. 398-Absorbed Dose Determination in External Beam Radiotherapy. Vienna, Austria.

Immel, A., Le Cabec, A., Bonazzi, M. et al. Effect of X-ray irradiation on ancient DNA in sub-fossil bones - Guidelines for safe X-ray imaging. Sci Rep 6, 32969 (2016). https://doi.org/10.1038/srep32969

Khan, M.F., 2005. The Physics of Radiation Therapy, The 4 edition. Lippincott Wiliams and Wilkins: New York.

Linskey, M.E., J.V. Kuo, J.K.C. Liu. 2015. General and Historical Considerations of Radiotherapy and Radiosurgery. Diakses $\begin{array}{lll}\text { pada } & 20 & \text { Juni } 2020 .\end{array}$ https://clinicalgate.com/general-andhistorical-considerations-of-radiotherapyand-radiosurgery/

Podgorsak. E.B. 2003. Radiation Oncology Physics : A Handbook for Teachers and Students. IAEA: Vienna.

Pratiwi, U., 2006. Aplikasi Analisis Citra Detail Phantom dengan Metode Konversi Data Digital ke Data Matrik untuk Meningkatkan Kontras Citra Menggunakan Film Imaging Plate. 
Jurnal Biosains Pascasarjana Vol. 22 (2020) pp

(C) (2020) Sekolah Pascasarjana Universitas Airlangga, Indonesia

FMIPA, Universitas Sebelas Maret:

Surakarta.

Pratiwi, U., 2010. Analisis Keluaran Berkas Radiasi Foton 10MV pada Pesawat Teleterapi Linear Accelerator. FMIPA, Universitas Sebelas Maret: Surakarta.

Tsiamas P, Sajo E, Theodorou K, Kappas C, Makrigiorgos $\mathrm{M}$, Marku $\mathrm{K}$ and Zygmanski, 2014. Beam Quality and Dose Perturbation of $6 \mathrm{MV}$ Flattening Filter Free Linac, Physica Medica, 30(1): 47-56

Vinny, Alvionita (2018) Pengaruh Variasi Kedalaman Target dan Luas Lapangan Penyinaran terhadap Penerimaan Dosis Radiasi pada Fantom Menggunakan Pesawat Linac Tipe Clinac Cx Di Rumah Sakit Universitas Andalas. Diploma Thesis. Universitas Andalas. 